\title{
Incidence of enteric pathogens in ugba, a traditional fermented food from African oil bean seeds (Pentaclethra macrophylla)
}

Princewill Chimezie Okorie ${ }^{1,2^{*}}$, Nurudeen Ayoade Olasupo ${ }^{2}$, Felicia Ngozi Anike ${ }^{3}$, Gloria Nwakego Elemo ${ }^{1}$ and Omoanghe Samuel Isikhuemhen ${ }^{3}$

\begin{abstract}
Background: The lack of good production practices and probable post-fermentation contaminations contribute to bacterial pathogen load in ugba, a fermented food made from African oil been seeds (Pentaclethra macrophylla Benth). Some of these bacteria are not easily detected using standard culturing techniques. The study used molecular-based approaches involving PCR, cloning and sequencing as well as culture-based methods to investigate the occurrence of pathogenic bacteria within the microbiome of ugba. Six samples (OK1-OK6) were purchased from different local markets within Lagos and Abia States in Nigeria and used in the study.

Results: A total of 14 pathogenic bacteria were identified among the bacteria diversity found in ugba. Two pathogens (11\%) were uniquely identified by cultural and biochemical characteristics, 12 pathogens (67\%) were uniquely identified by culture-independent (PCR-clone-based) method and 4 pathogens (22\%) were found in both methods. Enteric pathogens were common and Bacillus sp. was conspicuously absent. Escherichia coli and Staphylococcus aureus detected by cultural method in this study and elsewhere were not picked up by culture-independent method. This is the first report of the presence of Acinetobacter baumanii, Clostridium sartagofum, Enterococcus casseliflavus, Comamonas testosteronii, and Aeromonas sp. in ugba as identified by PCR-clone-based techniques. Though the genera Salmonella and Proteus have been associated with ugba in previous studies, the species-level identities were determined in this research by the culture-independent method used.
\end{abstract}

Conclusions: This study highlights the importance of using appropriate technologies and correct species identification strategies in studying microbiological quality and food safety issues in fermented foods in a developing country like Nigeria.

Keywords: Food safety, Pathogenic bacteria, Fermented foods, African oil bean seeds, Ugba

\section{Background}

'Ugba' is fermented African oil bean seed (Pentaclethra macrophylla Benth.) that is consumed as a delicacy and used as food flavoring condiment. The seeds are fermented under alkaline conditions (Olasupo et al. 2016). It is rich in protein and other essential nutrients, serving mainly as a source of protein, with distinctive economic,

\footnotetext{
*Correspondence: 61okorie@gmail.com

1 Department of Biotechnology, Federal Institute of Industrial Research Oshodi, Lagos, Nigeria

2Department of Microbiology, Faculty of Science, Lagos State University, Lagos, Nigeria

Full list of author information is available at the end of the article
}

social and cultural role among the consumers (Ogueke et al. 2010). Ugba is obtained through the processing of the large brown glossy seeds of the African oil bean seed involving- boiling the seeds in water for $4-12 \mathrm{~h}$ to soften the hard brown testa (shell), removing the shell, washing the kernel and slicing into long thin strips, and then mixing with salt (Odunfa and Oyeyiola 1985). The slices are packaged in small wraps with banana leaves (Musa sapientum) and left to ferment at room temperature for 2-5 days to yield the final product, ugba (Olasupo et al. 2016). There is no streamlined method, safety guideline or standards and so production practices and packaging 
is on individual/family basis. Although fermentation is a means of providing nutritious and palatable food, the safety of fermentation products especially in nonstandardized production practices is a major concern that needs adequate research.

Most studies of African fermented foods have focused on isolation and identification of desirable microorganisms involved in the fermentation process. (Gadaga et al. 2004; Okorie and Olasupo 2013b). There is limited information on the occurrence and growth of pathogens in African fermented foods compared to developed countries in Europe and North America. The traditional processing method of fermenting the African oil bean seed into ugba is riddled with issues of product safety and quality inconsistency. The growth and occurrence of organisms of public health importance in ugba is of great concern. Natural fermentation process used routinely in the fermentation of ugba allows participation of diverse microorganisms which may include contaminants. Therefore, the participation of pathogenic and spoilage microorganisms during its production is not surprising especially during fermentation under very poor hygiene condition. In previous studies, a few pathogens have been detected through the cultural-based method. Most of them except Eschericia coli and Staphylococcus aureus were identified only to the genus level (Ogueke et al. 2010; Eze et al. 2014). Anyanwu et al. (2016) and Ogbulie et al. (2014) have both reported the presence of E. coli, Klebsiella and Staphylococcus species in samples of ugba. The presence of these organisms in the product constitute a source of concern to the consumers who are increasingly becoming safety conscious.

Current records of possible pathogens in African fermented foods have been based on isolation of pure cultures, followed by phenotypic identification of isolated microorganisms (Ejiofor et al. 1987; Enujiugha and Akanbi 2008; Nwagu et al. 2010; Ogueke and Aririatu 2004; Okorie and Olasupo 2013a). In the case of ugba, studies reported in the literature on microbial quality were based on traditional culture and identification by phenotypic and biochemical methods. These organisms were detected using the routine culture-based method with its inherent weaknesses in detecting and resolving the identity of some organisms, especially the viable but unculturable ones. However, more than $96 \%$ of the earth's microorganisms are believed to be unculturable in the laboratory (Davey and Kell 1996). It is, therefore, suspected that the scope of contamination of ugba could be wider than have been recorded by these studies. The deployment of DNA-based techniques in the study of microbiological quality of ugba is needed to reveal the extent of microbiological hazard associated with its consumption. This is the first study that employed DNA based techniques in microbial evaluation of ugba. The main goal was to screen ugba samples using culturebased and culture independent (PCR-clone-based) methods and identify the pathogens that may be present. The diversity among total bacterial load was also evaluated.

\section{Methods}

\section{Sample collection and preparation}

Six samples (OK1 - Ok6) of fermented African oil bean seeds (Ugba) were purchased from different local markets in Nigeria. Five grams (5 g) of each sample were agitated vigorously with $10 \mathrm{ml}$ of phosphate buffered saline for $5 \mathrm{~min}$ and centrifuged at $7500 \mathrm{rpm}$ for $4 \mathrm{~min}$. The supernatants were used for bacterial isolation and also dried down for DNA extraction. Samples were stored at $-20{ }^{\circ} \mathrm{C}$ until used.

\section{Culture-Dependent-Phenotypic screening Bacteria isolation}

The supernatants were serially diluted and plated onto an all-purpose medium - nutrient agar and four different selective media - MacConkey agar, violet red bile agar, Salmonella/Shigella agar and Staphylococcus agar using the spread plate method. All media were prepared according to manufacturer's (Oxoid) protocol. Colonies were purified on same medium used for isolation, characterized and identified.

\section{Characterization and identification of isolates}

Isolates from each sample were characterized based on cultural, morphological and biochemical tests including sugar fermentation. For fermentation tests 8 sugars were tested at $1 \%$ concentration. Five milliliters of each sugar solution (glucose, sucrose, maltose, mannitol, lactose, fructose, sorbitol, xylose and arabinose) were filter sterilized and inoculated with the isolates individually. Other biochemical tests performed were gram reaction, catalase, oxidase, indole production, methyl red, VogesProskauer, urea hydrolysis, starch hydrolysis, gelatin hydrolysis, casein hydrolysis, nitrate reduction, coagulase and citrate utilization (Collins and Lyne 1989). These tests were performed according to standard microbiology protocols. Members of Enterobacteriaceae were further characterized using the analytical profile index kit (API 20E kit, Biomereux, France), according to manufacturer's specifications.

\section{Culture-Independent (PCR-clone based Screening) DNA extraction}

DNA was extracted from dried supernatants (pellets) of 6 ugba samples (OK1-OK6). Prior to use, pellets were separately suspended in $100 \mu \mathrm{l}$ of nuclease free water. Genomic DNA was isolated from each sample using QIAmp DNA 
Mini Kit (Qiagen, USA) according to the manufacturer's protocol. DNA concentration and purity were determined using Nanodrop (ND 1000) Spectrophotometer.

\section{PCR Amplification of genomic DNA}

PCR were carried out on genomic DNA from each sample to amplify genes coding for bacterial $16 \mathrm{~s}$ rRNA using $16 \mathrm{~s}$ primer sequence; Forward: 5'-CCTACGGG AGGCAGCAG-3' and Reverse 5'-CCGTCAATTCCTT TRAGTTT-3'. Amplification was performed in a thermal cycler (Eppendorf, Germany) in $25 \mu \mathrm{l}$ reaction volume consisting of $12.5 \mu \mathrm{L}$ GoTaq Green Master Mix (Promega), $1.25 \mu \mathrm{L}$ each of forward and reverse primers (Eurofins genomics), $9 \mu \mathrm{L}$ water and $1 \mu \mathrm{L}$ template DNA under the following conditions: denaturation $94{ }^{\circ} \mathrm{C} 35 \mathrm{~s}$, annealing $49{ }^{\circ} \mathrm{C} 35 \mathrm{~s}$, and extension $72{ }^{\circ} \mathrm{C} 1 \mathrm{~min}$ for 30 cycles.

\section{Cloning and sequencing of amplified fragments}

PCR products from each sample were cloned onto pGEM-T Easy Vector (Promega, USA), followed by transformation into JM109 competent Escherichia coli cells (Promega). A total of 384 positive clones were selected (64 clones $\times 6$ samples). Colony PCR was carried out on each clone with same primer pairs used for initial PCR. Amplified fragments were purified with ExoSAP-IT (Affymetrix, USA). Sequencing of forward and reverse strands was performed by Sanger method at Eurofins Genomics (Kentucky, USA). Sequencing primers were same as used for PCR amplification of the DNA fragments.

\section{Sequence analysis and bacteria identification}

Sequencing data were assembled, trimmed, and quality-checked by DNA Sequence Assembler v4 (2013), Heracle BioSoft, (www.DnaBaser.com). The resulting sequences were subsequently compared with deposited sequence information using the BLAST algorithm (http://blast.ncbi.nlm.nih.gov/Blast.cgi/ and http://www.ezbiocloud.net/)). 16S rRNA identification at the genus level was done at $\geq 97 \%$ identity, and species level, $\geq 99 \%$ identity. Scores due to poor sequence quality were considered as non-interpretable results.

\section{Results}

Culture-dependent and PCR-clone-based sequence methods were used to evaluate the microbial community of fermented African oil bean seeds. Bacterial diversity detected in this study is shown in (Fig. 1). A wide range of bacteria including pathogens were identified. The cultural method revealed diverse but limited number of bacteria. Six groups of bacteria that are of potential public health importance were identified using culture-based method (Table 1). These organisms were detected across the samples screened with Staphylococcus species and Escherichia coli isolated in five out of the six samples examined, Klebsiella and Proteus in four samples, Pseudomonas in two samples while Salmonella was detected in only one sample.

Three hundred and sixty-four (364) clones were selected using blue/white cloning technique (Fig 2). White bacteria colonies indicated positive cloning of the target $16 \mathrm{~S}$ rRNA fragment while blue colonies indicated negative cloning. More than $50 \%$ of cloned $16 \mathrm{~S}$ fragment were positive. The sequencing of cloned fragments revealed wider bacteria diversity and more pathogens in fermented ugba.

The relative abundance of pathogenic bacteria identified by culture-independent method (clone based technique) and their relative abundance in each sample is shown in (Fig. 3). Acinetobacter baumanii was the most

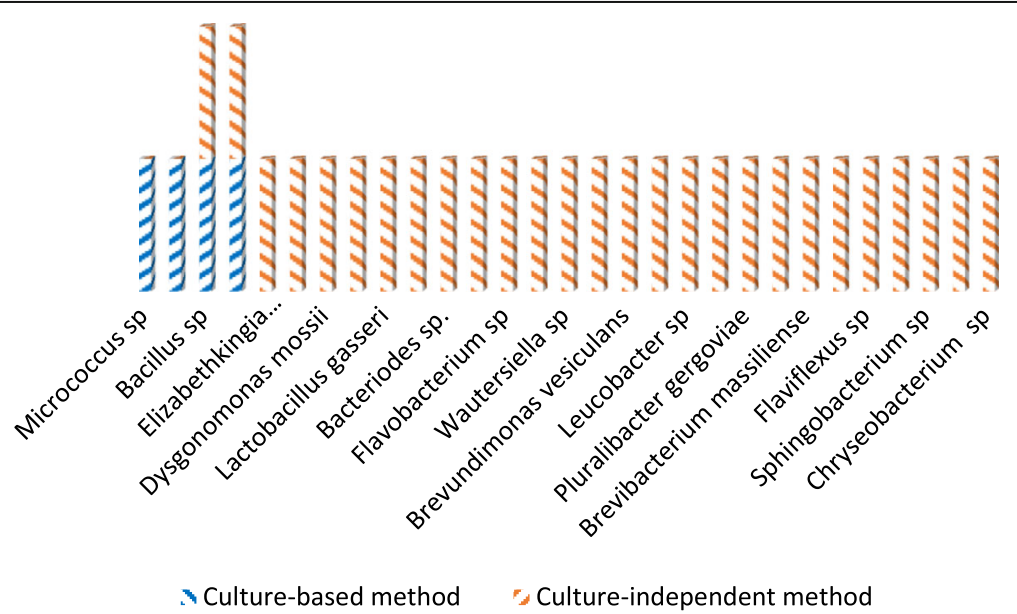

Fig. 1 Non-pathogenic bacteria uniquely detected by cultural and clone-based methods in ugba (fermented African oil bean seeds (Pentaclethra macrophylla Benth.). blue bars- bacteria detected by cultural method; orange bar- bacteria detected by clone-based method; blue and orange bar: bacterial detected by both methods 
Table 1 Phenotypic and biochemical features of pathogenic bacteria isolated from ugba, an indigenous Nigerian food produced from African oil bean (Pentaclethra macrophylla Benth)

\begin{tabular}{|c|c|c|c|c|c|c|}
\hline \multirow[b]{2}{*}{ Characteristics } & \multicolumn{6}{|l|}{ Bacteria isolates } \\
\hline & 1 & 2 & 3 & 4 & 5 & 6 \\
\hline Color/pigment & yellow & black & pink & pink & pink & green \\
\hline Gram reaction & + & - & - & - & - & - \\
\hline Cell shape & coccus & rod & rod & rod & rod & rod \\
\hline Catalase test & + & + & + & + & + & + \\
\hline Oxidase test & - & - & - & - & - & + \\
\hline Indole production & - & + & - & - & + & - \\
\hline Motility & - & + & - & + & + & + \\
\hline Methyl red test & - & + & + & - & + & - \\
\hline Voges-Proskauer & + & - & + & + & - & - \\
\hline \multicolumn{7}{|l|}{ Hydrolysis of } \\
\hline Urea & + & - & + & + & + & - \\
\hline Starch & - & - & + & + & - & - \\
\hline Gelatin & - & - & - & - & + & + \\
\hline Casein & - & - & + & - & - & - \\
\hline Nitrate reduction & + & + & + & - & - & + \\
\hline Coagulase test & + & - & + & - & - & - \\
\hline Citrate utilization & - & - & + & + & + & + \\
\hline \multicolumn{7}{|l|}{ Sugar Fermentation } \\
\hline Glucose & + & + & + & + & + & + \\
\hline Sucrose & + & + & + & + & + & + \\
\hline Maltose & + & + & + & + & + & + \\
\hline Mannitol & + & + & + & + & - & + \\
\hline Lactose & + & + & + & + & - & - \\
\hline Fructose & + & - & + & + & - & + \\
\hline Sorbitol & - & + & + & + & - & - \\
\hline Xylose & - & + & + & + & + & - \\
\hline Arabinose & - & + & + & + & - & + \\
\hline Probable identity & Staphylococcus aureus & Escherichia coli & Klebsiella sp. & Enterobacter sp & Proteus sp. & Pseudomonas sp. \\
\hline
\end{tabular}

abundant bacteria. It was detected in 4 out of 6 samples in 42 clones. Enterococcus feacalis was the most common pathogen among the sample; found in 5 out of 6 samples. It was the second most abundant with 27 clones. Clostridium sartagofum and Aeromonas sp. were the least abundant pathogens; found in only one sample and one clone each. The abundance of other pathogens ranged between 1 and 42 .

The presence of potential pathogens in the samples was detected by both cultural and culture-independent methods (Fig. 4). However, culture-independent method (PCR-clone-based method) revealed a wider bacterial diversity ( $>2$ fold) than the culture-based method. Sixty seven percent $(67 \%)$ of pathogens were uniquely identified by clone-based method, $11 \%$ by culture-based method and $22 \%$ by both methods (Fig. 5). Culture- independent method resolved the identity of detected pathogenic bacteria to species level (Fig. 4) while culture-based method identified most of them to genus level (Table 1).

\section{Discussion}

The lack of good production practices for fermented African oil bean seeds is a major setback in food safety standards of the product. African fermented oil bean seed is produced by cottage industries in ways defined by each producer, creating lapses that could lead to food contamination. These lapses in our vigilance for food safety have been responsible for outbreaks of serious food poisoning in different regions particularly in the continent of Africa (Campbell-Platt 1997; Olasupo et al. 2002). Our work seeks to draw attention to the issue of 


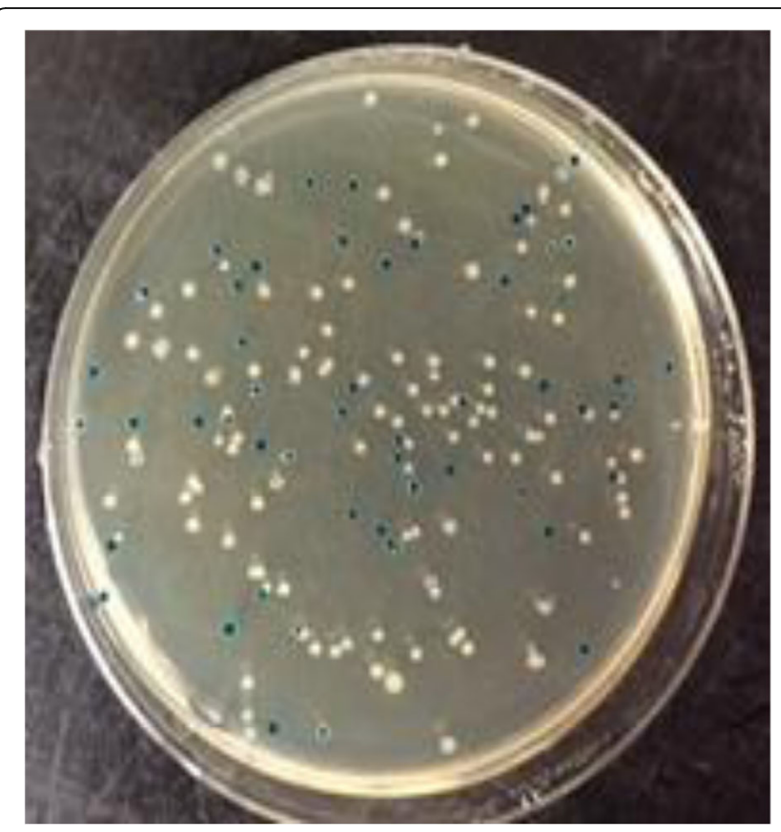

Fig. 2 Blue/white cloning of PCR products from samples of ugba (fermented African oil bean seeds Pentaclethra macrophylla Benth.). PCR fragments from DNA isolated from ugba samples were ligated unto pGEM-T plasmid and transformed into competent E. coli cells, and plated on Ampicillin-X-gal containing medium

safety and quality of traditionally fermented foods in Africa.

The consumption of fermented African oil bean seeds in Nigeria dates back to centuries ago. However, the issue of safety remains a major challenge, like some other traditional fermented foods produced in Africa. The method for its preparation and fermentation has remained unchanged and, still depends mainly on spontaneous fermentation process and use of local non-sterile utensils. Other potential sources of variability in bacterial type and load could be the food handler's hygienic status and lack of standardized manufacturing practice, leading to possible introduction of pathogenic organisms. The presence of some pathogens have been reported in fermented African oil bean seeds and this has included Escherichia coli and species of Staphylococcus, Klebsiella, and Proteus (Anyanwu et al. 2016; Eze et al. 2014; Isu and Njoku 1997; Ogbulie et al. 2014). Other pathogens that have been reported in other African fermented foods include Bacillus cereus, Salmonella sp. Vibrio cholera, Aeromonas sp., Campylobacter and Shigella (Gadaga et al. 2004). In a similar study on safety of traditional Nigerian fermented foods, Olasupo et al. (2002) reveals that microorganisms of public health concern that have been associated with Nigerian fermented foods include Staphylococcus aureus, Klebsiella sp., E. coli, Salmonella sp., Bacillus subtilis, and Enterococcus faecalis.

To ensure food safety, it is critically important that quality control standards including accurate methods for identifying pathogens be adopted and followed, in order to understand the extent of danger posed by the consumption of such food. Previous efforts in identifying possible pathogens in ugba have been predominantly culture-based, involving the isolation and identification methods using phenotypic tools. This identification scheme has the inherent weakness of not being able to detect and identify viable but unculturable organisms in a food matrix. The results obtained in this study using
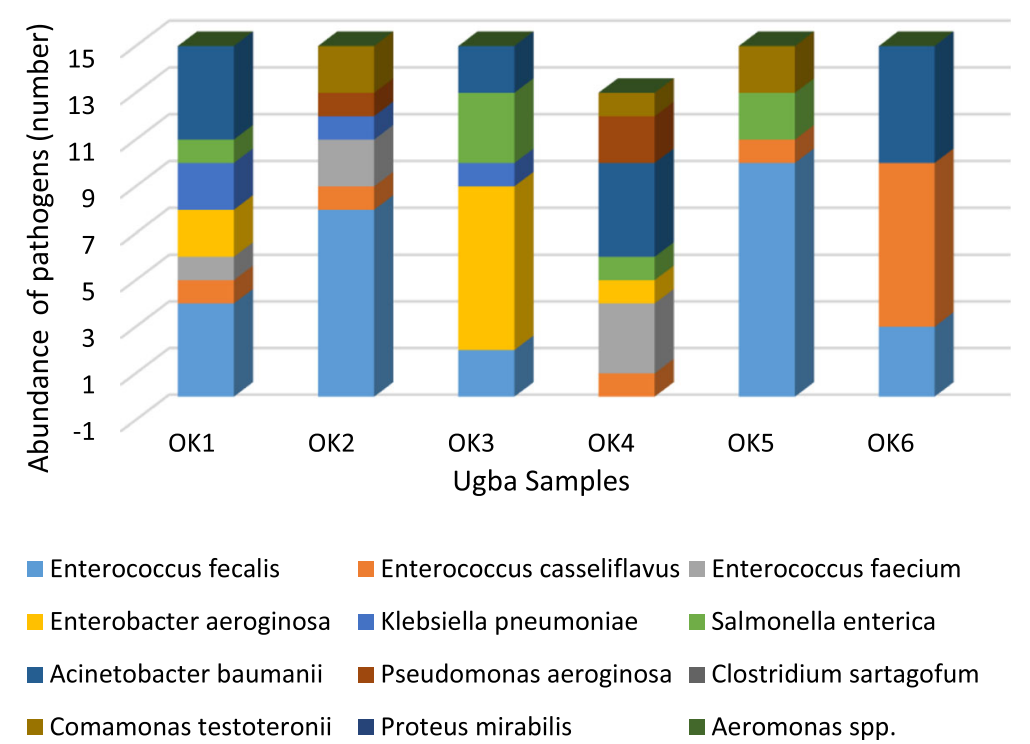

Fig. 3 Type and relative abundance of pathogenic bacteria detected in six samples (OK1-OK6) of ugba (fermented African oil bean seeds Pentaclethra macrophylla Benth.) by clone-based method 


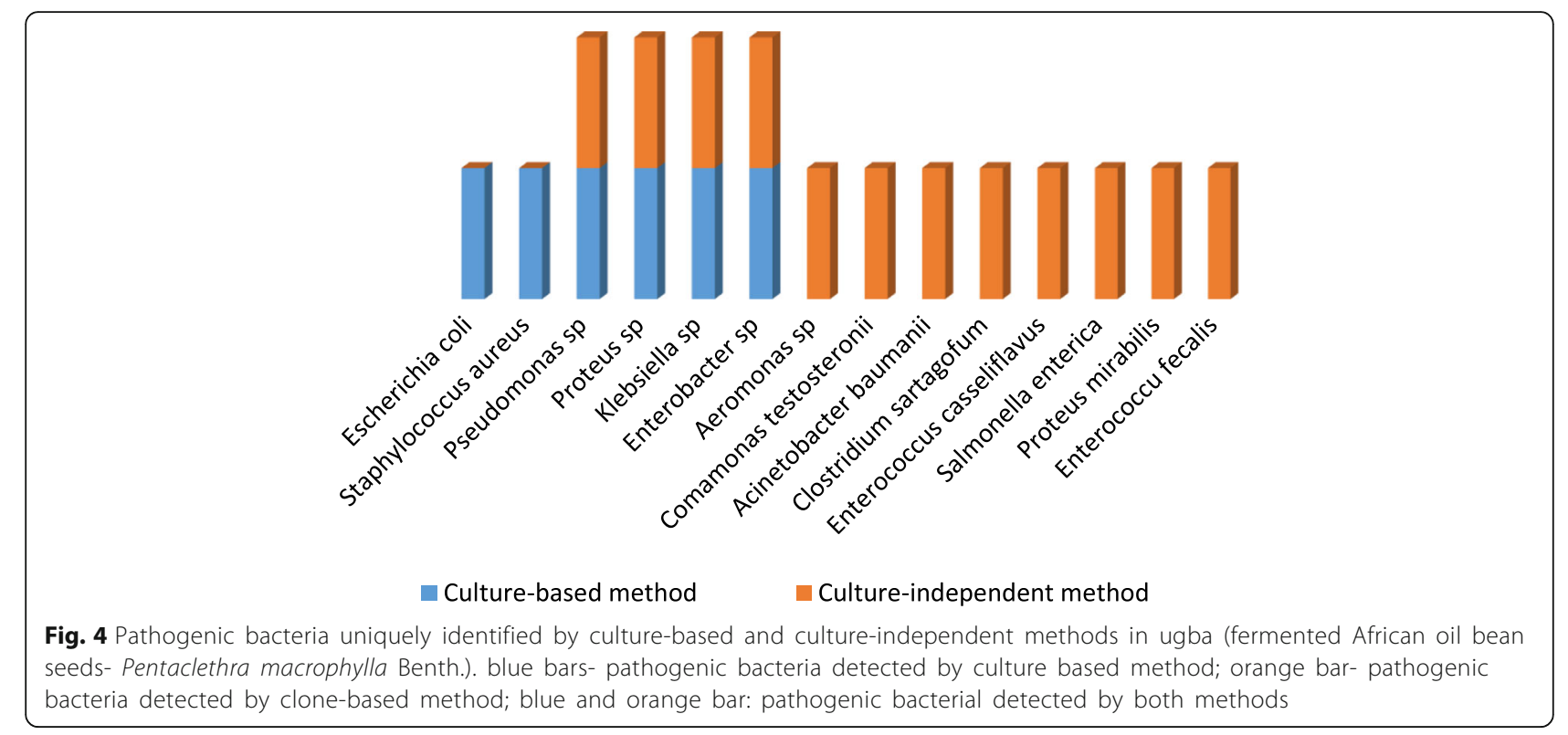

the phenotypic method of screening of cultured bacteria are consistent with what has been reported in the literature. However, as expected, DNA sequence based identification scheme employed in this study has shown that the range of organisms that could be of public health importance associated with ugba, could be much wider than what has been reported in literature and in this study, using culture-based methods. A variety of pathogens were reported, for the first time, in this study as being found in fermented African oil bean seed (ugba) using the PCR-clone library technique. Finally, while bacteria belonging to the genera Salmonella and Proteus have been associated with ugba in the past, their species-level identities were determined in the present study as Salmonella enterica and Proteus mirabilis respectively.

It is believed that molecular methods have a superior ability to detect and identify organisms that are viable but may not be culturable or are in very low numbers and could not be detected by pure culture isolation and phenotypic characterization. This accounted for the wider bacteria diversity and potential pathogens detected in this study. This belief is shared by Gao and Moore (Gao and Moore 1996); Schloss and Handelsman (Schloss and Handelsman 2005) who have demonstrated that molecular techniques, such as representational difference analysis, consensus sequence-based PCR, and complementary DNA library screening, have led to the identification of several previously unculturable infectious agents. Rhoads et al. (2012), in a study evaluating culturing versus $16 \mathrm{~S}$ rRNA sequencing as tools for identifying bacterial species in human chronic wound infection, identified 145 unique genera using molecular methods, whereas only 14 unique genera were identified using aerobic culture methods.

Davey (Davey and Kell 1996) and Gunasekera et al. 2003 noted that a major disadvantage of using culturebased methods in the analysis of food samples is their failure to detect viable but non-culturable organisms. They raised doubts about the effectiveness of culturebased methods in the recovery of sub-lethally injured cells that may occur in heat treated products such as

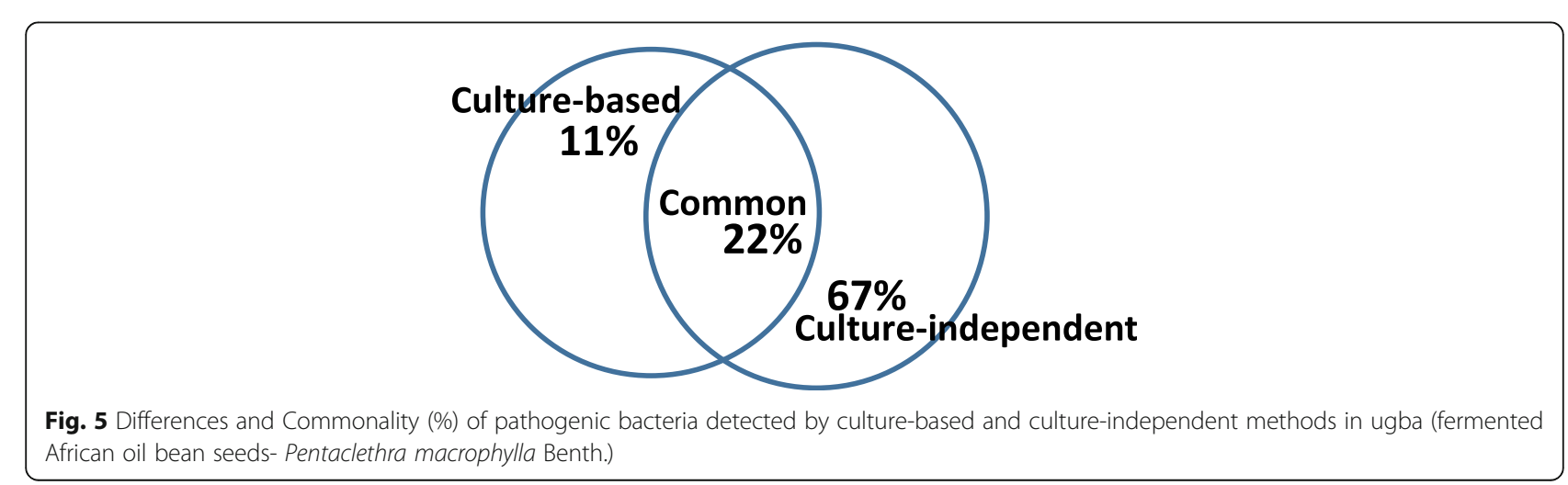


pasteurized milk. Since the fermentation process of ugba is usually terminated by boiling the final product in water, it is possible that the boiling process could have injured but not eliminated some of the bacteria and rendered them unculturable. However, because the molecular methods are culture independent, such cells are detected and identified. This and post fermentation handling and processing could therefore account for the wider range of bacteria diversity and potentially pathogenic bacterial genera/species detected by molecular techniques, against what was detected by cultural methods in ugba.

In addition to some other bacteria identified in literature, this study has reported for the first time various types of possible pathogenic bacteria in ugba including Enterococcus faecalis, Enterococcus casseliflavus, Enterobacter aeroginosa, Klebsilla pneumoniae, Salmonella enterica, Proteus mirabilis, Aeromonas sp. Enterobacter sp., Enterococcus faecium, Comamonas testosteronii and Clostridium sartagofum. Many of these organisms are part of the gastrointestinal microbiota of the human population, and their presence in the product is suggestive of fecal contamination. This is an indication of the poor hygiene in the processing environment and lack of good manufacturing practice. Fecal-oral route of transmission for many bacterial food-borne diseases is very significant; therefore, basic hygienic measures are an essential step for improving food safety. This study therefore, underscores the need to develop a standardized protocol for the production of this product, to ensure its quality and safety.

It remains possible that the presence of these bacteria of possible public health importance identified by this study is due to post-fermentation contamination. It is also possible however that their presence in ugba could be from the raw materials especially water, used in the production process. Since fermentation of African oil bean seeds has been shown to be an alkaline process, up to $\mathrm{pH} 8.2$ (Ogueke et al. 2015; Olasupo et al. 2016), the antimicrobial effect often associated with most fermented food products due to their low $\mathrm{pH}$ is probably lacking in ugba. It is therefore possible that these organisms survived the fermentation process.

Whether the bacteria identified by this study were post-fermentation contaminants or they survived the fermentation process, their presence in ugba pose health risks to the consuming public. This is especially so as ugba purchased in the market place is sometimes eaten without pre-heating or cooking. Although, the enterotoxigenic potential of the detected organisms are yet to be determined, their presence in foods could serve as indication for the need to promote awareness about the possible health hazards due to handling and processing of traditional fermented foods.

\section{Conclusion}

This study clearly demonstrates the presence of pathogenic bacteria in ugba. This constitutes health and food safety concerns for consumers. The molecular tools employed have expanded the scope of possible pathogens associated with ugba. This is the first time that Enterococcus casseliflavus, Acinetobacter baumanii, Clostridium sartagofum. Comamonas testosteronii, and Aeromonas sp. are reported to be found on ugba samples. However, it is necessary to study larger sample size to determine the occurrence and abundance of these organisms in ugba across Nigeria. Nevertheless, it is pertinent to develop a standardized protocol for the production of ugba, in order to improve its quality and safety. It also underscores the need to maintain improved hygienic standards and good manufacturing practice (GMP) in the preparation of fermented condiments generally and ugba in particular.

\begin{abstract}
Acknowledgements
The authors are grateful to Miss Janelle Robnson, of Agricultural and Technical University, North Carolina, USA and Mr. Olatope S. O. of Federal Institute of Industrial Research, Lagos Nigeria for their assistance in the execution of this work. None of the authors have any competing interest in the manuscript.

Funding

Self funded.

\section{Authors' contributions}

PCO, NAO, GNE, OSI designed the study. PCO and FNA conducted the experiment under the supervision of OSI and NAO. PCO, OSI and FNA performed the processing of data. All authors read and approved the final manuscript.
\end{abstract}

\section{Competing interest}

The authors declare that they have no competing interests.

\section{Author details}

${ }^{1}$ Department of Biotechnology, Federal Institute of Industrial Research Oshodi, Lagos, Nigeria. ${ }^{2}$ Department of Microbiology, Faculty of Science, Lagos State University, Lagos, Nigeria. ${ }^{3}$ Department of Natural Resources and Environmental Design, North Carolina Agricultural and Technical State University, Greensboro, North Carolina, USA.

Received: 22 February 2017 Accepted: 24 July 2017 Published online: 31 July 2017

\section{References}

Anyanwu NCJ, Okonkwo OL, Iheanacho CN, Ajide B. Microbiological and nutritional qualities of fermented ugba (Pentaclethra macrophylla Bentham) sold in Mbaise, Imo state, Nigeria. Ann Res Rev Biol. 2016;9(4):1-8.

Campbell-Platt G. Editorial: Food control and its impact on food safety. Food Contr. 1997:1:1-3.

Collins CH, Lyne PM. Microbiological methods. 6th ed. London: Butterworths; 1989. p. 129-30.

Davey HM, Kell DB. Flow cytometry and cell sorting of heterogeneous microbial populations: the importance of single cell analyses. Microbiol Rev. 1996;60: 641-96.

Ejiofor MAN, Oti E, Okafor JC. Studies on the fermentation of seeds of the African oil bean tree (Pentaclethra macrophylla Benth). Int Tree Crops J. 1987:4:135-44. Enujiugha VA 
Enujiugha VN, Akanbi CT. Quality evaluation of canned fermented African oil bean seed slices during ambient storage. Afr J Food Sci. 2008;2:54-9.

Eze VC, Onwuakor CE, Ukeka E. Proximate composition, biochemical and microbiological changes associated with fermenting African oil bean (Pentaclethra macrophylla Benth.) seeds. Amer J Microbiol. 2014;2(5):674-81.

Gadaga TH, Nyanga LK, Mutukumira AN. The occurrence, growth and control of pathogens in African fermented foods. Afr J Food Agric Nutr Dev. 2004;4(1): 406-13.

Gao SJ, Moore PS. Molecular approaches to the identification of unculturable infectious agents. Emerg Infect Dis. 1996;2(3):159-67.

Gunasekera TS, Dorasch MR, Slado MB, Veal DA. Specific detection of Pseudomonas spp in milk by fluorescent in situ hybridization using ribosomal RNA directed probes. J Appl Microbiol. 2003;94:936-45.

Isu NR, Njoku HO. An evaluation of the microflora associated with fermented African oil bean (Pentaclethra macrophylla Bentham) seeds during ugba production. Plt Foods Hum Nutr. 1997;51:145-57.

Nwagu TN, Amadi C, Alaekwe O. Role of bacteria isolates in the spoilage of fermented African Oil Bean Seed Ugba. Pakistan J. Biol. Sci. 2010;13:497-503.

Odunfa SA, Oyeyiola GF. Microbiological study of the fermentation of ugba: A Nigerian indigenous fermented food flavor. J Plt Foods. 1985;6:155-63.

Ogbulie TE, Nsofor CA, Nze FC. Bacteria species associated with ugba (Pentaclethra macrophylla Bentham) produced traditionally and in the laboratory and the effect of fermentation on product of oligosaccharide hydrolysis. Nig. Food J. 2014;32(2):73-80.

Ogueke CC, Anosike F, Owuamanam Cl. Prediction of amino nitrogen during ugba (Pentaclethra macrophylla) production under different fermentation variables: A response surface approach. Nig. Food J. 2015;33:61-6.

Ogueke CC, Aririatu LE. Microbial and organoleptic changes associated with ugba stored at ambient temperature. Nig Food J. 2004;22:133-40.

Ogueke CC, Nwosu JN, Owuamanam Cl, Iwouno JN. Ugba, the fermented African oilbean seeds; its production, chemical composition, preservation, and health benefits. Pakistan J Biol Sci. 2010;13:489-96.

Olasupo NA, Okorie PC, Oguntoyinbo FA. The biotechnology of ugba, a Nigerian traditional fermented food condiment. Front Microbiol. 2016;7:1153-61.

Olasupo NA, Smith SI, Akinsinde KA. Examination of microbial status of selected indigenous fermented foods in Nigeria. J Food Safety. 2002;22:85-93.

Okorie PC, Olasupo NA. Growth and extracellular enzyme production by microorganisms isolated from ugba- an indigenous Nigerian fermented food. Afr J Biotechnol. 2013a;12(26):4158-67.

Okorie PC, Olasupo NA. Controlled fermentation and preservation of ugba - an indigenous Nigerian fermented food. Spring. 2013b;2:470-8.

Rhoads DD, Cox SB, Rees EJ, Sun Y, Wolcott RD. Clinical identification of bacteria in human chronic wound infection: culturing vs $16 \mathrm{~s}$ rDNA sequencing. BMC Infect Dis. 2012;12:321-8.

Schloss PD, Handelsman J. Metagenomics for studying unculturable microorganisms: cutting the Gordian knot. Gen Biol. 2005;2005(6):229-35.

\section{Submit your manuscript to a SpringerOpen ${ }^{\circ}$ journal and benefit from:}

- Convenient online submission

- Rigorous peer review

- Open access: articles freely available online

- High visibility within the field

- Retaining the copyright to your article

Submit your next manuscript at $>$ springeropen.com 